\title{
THE UNDERSTANDING OF MEANING IN LITERARY LEARNING THROUGH SCIENTIFIC APPROACH
}

\author{
Juliaans E. R. Marantika \\ Julians.marantika@yahoo.com \\ FKIP Universitas Pattimura - Ambon
}

\begin{abstract}
The works of literature greatly contribute to a nation's characteristics and personality. Understanding a literary work means being able to grasp moral values or messages that are useful for social life. However, understanding a literary text is not as easy as understanding a non-literary text. The main reason is that the literary text bound to several forming conventions such as the language convention, literature, and cultural conventions. To understand this, students must be trained through education and teaching. Literary learning which can produce a good understanding should prioritize the process to familiarize students with the conventions that bind literary works through heuristic and hermeneutic reading. The 2013 curriculum, requires a change in the paradigm of the teacher's thinking towards planning and implementing learning based on a scientific approach. The important point that should be understood by the teachers is literary learning, according to any curriculum, aims to provide literary knowledge understanding and appreciation to the students. It indicates that literary learning should be designed not only to improve literary knowledge but also to express the values that contained. The application of semiotic analysis methods in literary learning including short stories or poetry can be adapted to the steps of teaching based on the scientific approach known as 5 principles, which are observing, questioning, exploring, associating, and communicating/presenting as required by 2013 curriculum. In this context, the expression of the meaning of literary texts is done through observing, reading, repeating, comparing texts (heuristic readings), and continued by exploring and tracing the meaning of texts (hermeneutic readings) and drawing conclusions as a whole.
\end{abstract}

Keywords: Literary Learning, Scientific Approach.

\section{Introduction}

The core of literature can be depicted as a mirror that reflects any events in human life in a certain era. Through the phenomenon that occurs, the generation that born afterward can learn about civilization from a different era. It is because the writing of the literary works always related to the socio-cultural context of the people at a certain time. In short can be concluded that the presence of the works of literature in all its forms is the result of human creations, tastes, and initiatives that contain many life values that are useful for shaping one's character and personality. Thus, the work of literature can shape one's language and contribute to one's knowledge about the social culture which is needed in real social life. 
Furthermore, the importance of these literary works should also be accompanied by efforts to familiarize literary works with the youth. One of the efforts is by putting the literary learning in formal education, starting from elementary to higher education level. Through this, the learner is hoped to be able to understand and appreciate the literary works.

Drawing from the picture above, there are several facts about literary learning in Indonesia that that still need some concerns which are; First, both in KTSP curriculum or in 2013 Curriculum, the literary learning has had enough considerable attention from the Indonesian government, although it is still part of Indonesian subjects. In particular, the 2013 curriculum requires a change in paradigm and mindset which is different from the application of the previous curriculum and this must be realized by the teacher in the teaching and learning process in schools. The learning process is expected to be carried through studentcentered learning by applying a scientific approach that is supported by appropriate learning models. Second, not all language teachers can create a learning process that can attract students to love literature. Therefore, literary learning is no longer merely to memorizing the names of writers and their work, but rather to encourage students to understand and appreciate the meaning of various literary texts. Third, most of the teachers who teach literature are Indonesian teachers who do not have adequate literary competence. This became the main obstacle to plan and implement good literary learning, which prevents the students to not only know the literature but also able to appreciate the literary works. Fourth, most students cannot grasp the message or the social value from the literary works that they read.

From the elementary to the higher level, the literary works from various genres, only used as a text for learning Indonesian. The learning objective is only to focus on understanding the text. Though, understanding a literary text is not the same as understanding non-literary texts. Literary texts have certain characters that require different reading techniques. This is because the literary works are created by considering the language code, cultural code, and literary code. It means that reading and understanding literary texts, demanding an understanding of those three codes.

Based on the facts above, also as in line with the role of literature in developing the character and personality of the youth, then the teacher should manage the literary learning professionally to achieve its goals. It is an important and urgent call for teachers to conduct studies on the development of an effective literary learning model that is suitable for the objectives of the 2013 Curriculum where the goal is to improve literary skills for the students.

\section{Problems}

Generally, the purpose of literary learning at all schools with their curriculum is oriented to literary knowledge and literary appreciation. The orientation can be divided into literary knowing, doing, being, appreciation, expression, and production (Sumitro 2013). It means that the design of literary learning is not only to increase students' literary knowledge, such as mastering figures or writers from various eras and their work but also to understand the 
meaning or values contained in the literary work that they read. Consequently, the literary learning that can produce the above understanding, should prioritize the process of being able to familiarize students with literary works and conventions contained. Related to the implementation of the 2013 curriculum which requires a change of paradigm and mindset of all parties involved, especially teachers or schools, then they should be able to implement an effective different learning process. The learning process is expected to be implemented through studentcentered learning which is supported by modern learning models. As a result, some questions that arise from this situation are; Do the language teacher in the school already has sufficient literary competence? Are language teachers ready to design learning that can improve student understanding? Are language teachers able to choose teaching material that can increase student interest? Does the language teacher have sufficient capacity in carrying out the teaching and learning process of literature according to the scientific approach?

\section{Discussion}

In this section, several concepts will be presented to answer the problems. Those concepts will explain about the understanding of literary works, approaches used to design literary learning, analytical methods under the objectives and approaches of literary learning, and the implementation of scientific approaches in literary learning.

\section{The Understanding of Literary Works}

Commonly, the understanding is known as intellectual abilities in the cognitive realm, along with knowledge, application, analysis, synthesis, and evaluation. Bloom (1981), states that understanding is an intellectual ability and skill which widely used by learners to express their level of absorption of a concept that has been learned. According to Dilthey as stated in Palmer (2003), the understanding is not only related to the mastery of rational concepts such as mathematical problems, but more than that is an activity to capture and integrate the thoughts of others with our thoughts. Thus, the understanding can be interpreted as a soul process to expand one's experience which can ultimately free from the isolation of thought.

To reach a certain level of understanding, the reader (in this case the recipient of the concept in writing) must associate the elements of the language in the text referred to the knowledge they possessed (Werlich 1986). Pearson and Johnson as Cited in Nunan (1991), state that understanding is divide into several principles which are; (1) The understanding is an active activity, not a passive one. The reader should be able to interpret the meaning of the text; (2) The understanding requires a large amount of conclusion. For instance, the conclusions needed to understand even the simplest prose writing can be confusing. (3). The understanding is the dialog between the writer and the reader. As a consequence, when a reader tries to interpret the statement according to their perception of the information conveyed by the author, it can be said that to understand a written text is not merely a complicated activity in defines the symbols from the text, but far more than that. In this case, the reader is expected 
to be able to make conclusions by integrating the meaning of the language symbols that are listed in the text with the knowledge that the reader already has.

In the context of literary works, Ludwig (1994) explains that understanding and interpreting are two separate activities that mutually support the results of understanding the meaning of literary works. The understanding (verstehen) is the first phase activity, aimed at constructing or composing the meaning of the text. While interpreting is the next step, aimed at explaining the reconstructed meaning. It means that the ability to explain meaning in the interpretation phase is very dependent on the ability to reconstruct the meaning of the supporting elements of poetry. Teeuw (1991) explains that the efforts to understand at the early stage can reduce misunderstanding of the meaning interpretation of literary works, especially poetry. It is because understanding literary works require different expertise than non-literary works. This expertise concerns the ability to analyze conventions, both general and specific. Without knowledge of the convention, the meaning will be difficult to be expressed.

The explanation above illustrates that the understanding of the meaning of literary works is not easy if it is associated with the existence and characteristics that increasingly complex.

If the meaning of non-literary work is easier to be understood because of the use of normative language or ordinary language, then literary works use language that deviates from the normative grammar. It means that to understand and to give a meaning to literary works is not easy without understanding literary conventions and conventions of literary signs which are the main requirements for readers to understand. The mastery of the convention or code system includes 1) Language codes, including figurative languages, rhetoric, ambiguity, contradiction, and nonsense; 2) cultural codes, as well as 3) distinctive literary codes, such as visual conventions that include stanzas, verse lines, enjambments, rhymes, typography, and homolog, etc.

Moody (1971), states that the understanding of literary works from learners can be measured through the success on how learner expressing something about literary works that they read, which including 4 (four) categories such as 1) information; 2) concept; 3) perspective and 4) appreciation. The first category relates to understanding the structure of literary works that are read. The second category relates to learners' perceptions of how they organize the information or structure of the literary works. The third category relates to the learner's view of the literary work being read. For instance, the view of the meanings that can be expressed and their relationship with the reader. While the fourth category relates to the learner's assessment of the use of the language in literary works, such as the effect of choosing certain words or sentences on the image of a particular character. Thus, it can be said that someone who understands literary works in depth (full of appreciation) usually feels what the writer wrote while being able to absorb the values contained.

From the explanation above, it can be concluded that what is meant by understanding the literary works in this study is the ability of the reader to capture and master the meaning through the information and concepts of the text they read and be able to conclude and interpret these meanings as a whole under their 
perceptions. These skills concern the signs or conventions of language and literature that consist of 1) The form of the writing and text-forming elements either related to linguistic elements such as the use of figurative language, as well as non-linguistic elements; 2) The disclosure of the implicit meaning of all conventions and literary signs including associative meanings, feelings, themes, tones, and mandates (intentions), figure or character, etc.; 3) The disclosure of text messages and 4) The conclusion of overall meaning.

In literary learning, the level of understanding is also determined by the selection of texts to be read. It is because, principally, the text that is read must have a relationship with the capacity of the reader. It means that the success of learning to improve the understanding is also determined by the ability of teachers to choose a suitable text to be used as teaching material. The text should be appropriate for the age and interests of the learner. According to Moody (1971), there are several criteria for selecting the literary text work that should be considered by the teacher which are the age of the learner, language, psychology, and background themes. Furthermore, he explains that the thing to be considered is the difficulty level of the text language with the capacity of the learner. The difficulty level can be measured from the grammar and diversity of vocabulary in the text. While the psychological aspect is associated with the interest and enthusiasm of learners towards the text. The last aspect, background, refers to the selection of themes that are familiar to the learner. In line with that, Collie and Slater (1987) state that learner needs, interests, cultural background, and language level are some aspects that must be considered by literature teachers in choosing teaching materials, so they can be relevant to the learners to achieve the level of the understanding. Also, Glaap, Bausch, Christ, and Krumn (1995) state that literary works that have been chosen must need the criteria such as the universality, authenticity, and actuality of the text.

\section{The Literary Teaching Method}

As explained before, the literary works are built by some elements which are different from the non-literary text. Those elements are related to the physical and mental elements.

The physical and mental elements are connected and combined as a whole which allows a literary text not only to reflect the beauty and imagination for its readers but also for its structural complexity. The complexity of the literary works can be seen from the combination of poetical features that are used, to build as much image the reader can get (Altenbernd and Lewis 1970). While on the other hand, the complexity of the structure requires an initial assessment or analysis to understand the meaning of the constituent elements (Hill 1966). Nurgiyantoro (2002) states that the need for the analysis is not only intended to look for the meaning of each constituent element, but also to look for relationships between the elements that can form the overall meaning of the text. The ability to analyze the meaning of elements, and the ability to look for relationships between elements to determine the overall meaning of a text, will only be obtained through systematic and repetitive practice. 
The systematic practice will give good results if it is designed in a systematic literary learning process which not only emphasizes teaching objectives on theoretical knowledge but also allows learners to improve their abilities and skills in appreciating literary works through the process of interaction and transactions with learned literature (Gani 1986). Furthermore, Teeuw (1991) argues that literary teaching should be able to familiarize learners with existing conventions. This teaching model will help to develop students' sensitivity to the convention, in recognizing the basic elements of the complex when interpreted. In other words, the teaching model that familiarizes learners with these conventions will ease the learners to not only look for meaning but also to help them to grasp the meaning of the text they read through their own experience.

Moody (1991) states that there is two basic literature teaching method which should be understood by the teachers such as; 1) Literature as experience; and 2) Literature as language.

The first principle relates to teachers' efforts to provide new experiences for students about any matters in life that must be experienced, known, and traced to be felt. As a consequence, the teacher should give the widest possibilities for students to actively developing their abilities.

While the second principle begins with the assumption that teaching literature is an operational language teaching process. Essentially, a literary work is a collection of words that must be analyzed or searched for its meaning.

Based on those two principles, Moody suggests that literary teaching should use a suitable method which can build students' understanding by involving comprehensive language skills. The method must provide opportunities for students to express their abilities through extensive and intensive reading. Both extensive and intensive reading is supported by each other, but specifically, in the teaching of poetry, the method of intensive reading is suggested to be used.

It because the intensive reading provides an opportunity for students for a depth detail analysis in all the constituent elements and conventions which is written in a text.

\section{The Analysis Literary Works Method}

A method for analyzing the literary works which can be used for a comprehensive understanding is the semiotic method. This method was derived from dissatisfaction with the study of structuralism which was only limited to the study of the intrinsic aspects of literary works. It is contradicted with the reality of the literary works which contained its system that cannot be separated such as problems of creation, problems of expression, and even problems of acceptance by the readers. The literature studies that only focusing on intrinsic aspects like this, according to Teeuw (1984), have weaknesses. The studies that conducted will separate the literary works from the framework of literary history and alienate literary works from the role of the reader as builder meaning in interpretation, also will eliminate the context and function.

In other words, the existence of semiotic methods in literary studies can complement the weaknesses of structuralism studies in expressing the meaning of the text as a whole. 
The semiotic method itself is derived from the assumption that literary works have a system and their world which is presented before the reader as a reality. It contains communicative potential through distinctive language symbols that have artistic and dramatic values. Those symbols of literary language which has artistic and dramatic values are the creative subjective impetus from the creator, due to limited space. The work style expression which utilizes all the figures or poetic signs is considered as a sign system. The disclosure meaning is highly dependent on the complexity of the literary conventions. The study of the sign is known as semiotic or semiology which in terms, comes from the ancient Greek word semeion which means sign in English. The term semiotic in linguistic studies have been known as the field of science that studies the signs or symbols and everything related to it (Nöth 1990).

In the context of literary studies, semiotic signs are known as conventions that cover several sets of signs. These units include sound, word, diction, figurative language, and sentences: sentence style or language style. Besides, there are also additional conventions such as taxation, enjambment, typography, association, and other conventions that build meaning in literature. The disclosure of the relationship between the sign and its signifier is formed through the understanding of the conventions. According to Riffatere (1994), that meaning complexity is considered as a second level semiotic system. If there is someone who wants to give a semiotic meaning, then it must be done through heuristic and hermeneutic/retroactive reading. Heuristic reading is the reading of literary works on the first level of semiotic systems. The meaning of understanding in the heuristic reading is merely about the language convention. In this context, the reader uses his linguistic competence for only assuming that language or words have referential meanings or relationships with things. At this stage, the reader is prepared to understand the semantic meaning of words or phrases that will later be associated with certain contexts according to poetic signs for the next readings. It means that the heuristic reading will only be resulting in a literal or explicit meaning. On the other hand, hermeneutic reading or understanding of the work at the second level of semiotic is a re-reading (retroactive) after the disclosure of the language meaning by giving literary conventions. At this stage, the reader is trained to memorize and modify the text with their understanding by using the poetry signs. The process of understanding is done by repeating, looking back, comparing, etc. This is the stage where the reader tries to express the implicit meaning that previously could not be expressed through the heuristic reader.

From the explanation above, it can be concluded that there are two ways to process the understanding of literary texts according to the semiotic method, which is heuristic reading and hermeneutic reading. The first way is used to help the students to understand a text at the level of mimesis (language conventions). While the second way is used to analyzes a text, to reveal high-level meaning (understanding literary conventions). The results of the first-level analysis, then linked to the second level for a whole-text understanding.

The steps of the analysis according to the semiotic method are as follows: 1) text analysis based on language conventions through heuristic reading. At this 
stage the learner is directed to understand the meaning of the text from the context of the written language; 2) seek for relationships between elements as a whole; 3) define the meaning of the elements based on the literary conventions; 4) determine whole (overall) meaning in a semiotic framework through hermeneutic reading; 5) make a synthesis.

\section{The Scientific Approach In Literary Learning}

The scientific approach in the learning process is a strong point from the 2013 curriculum existence. The scientific approach is believed to be the golden bridge of students' attitudes, knowledge, and skills. It is because learning itself is a scientific process. The scientific process refers to techniques that are used to investigate a phenomenon, gaining new knowledge, then correcting it by combining previous knowledge. This scientific approach emphasizes the involvement of students in learning intensely, creatively, and independently. In this approach, success can be measured from the student's development when they are starting to take some scientific steps starting from observing, asking questions, reasoning, trying, and communicating/presenting. Thus, it can be concluded that scientific learning is a way of learning that adopts scientific steps in building knowledge through scientific methods. The learning model needed is one that capable of producing the ability to learn (Joice and Wall 1996). The main point of scientific learning is not only the acquisition of knowledge, skills, and attitudes but more importantly is how the knowledge, skills, and attitudes are obtained by students (Zamroni 2000). In this case, scientific learning not only is measured by learning outcomes as the final point but the learning process. Therefore, scientific learning emphasizes processing skills. Process-skills-based-learning model is a learning model that integrates process skills with the presentation system as a whole (Beyer 1991). In this case, the students are considered as learning subjects that need to be actively involved in the learning process, while the teacher is only as a facilitator who guides student activities. The students are expected to carry out the process of finding regarding learning material. Thus, students are directed to discover for themselves various facts, build new concepts and values needed in life (Nur 1998).

Following the characteristics of Indonesian Language and Literature as part of natural science, learning Indonesian Language and Literature must reflect the competence of scientific attitudes, scientific thinking, and scientific work skills. Learning activities carried out through the process of observing, asking, trying, associating, and communicating/presenting with details as followed: 1) Observing, aimed to make learning closely related to the context of real situations that will be faced in daily life. The process of observing facts or phenomena includes seeking information, seeing, listening, and reading; 2) Questioning, carried out as a process of building students' knowledge in the form of concepts, principles, procedures, law, and theory, even metacognitive thinking. The aim is for students, to have critical thinking skills critically, logically, and systematically. The questioning process is done through discussion and group work and class discussions. The practice of group discussion gives space for freedom to express ideas in their language, including using local languages; 3) Practicing, aimed to 
increase student curiosity, develop creativity, and scientific work skills. This activity includes planning, designing, and carrying out experiments, as well as obtaining, presenting, and processing data. The usage of learning resources including computerization is highly recommended in this activity; 4) Associating, aimed to build the thinking and scientific ability. The teachers can design some situation which helps the students to do activities such as analyzing data, grouping, making categories, inferring and predicting/estimating by utilizing discussion or practice worksheets; and 5) Communicating/Presenting, aimed to help the students to convey the results of conceptualization in oral, written, drawing/sketch, diagram, or graphic form. This activity is carried out so that students can communicate their knowledge, skills, and applications, as well as students' creations through presentations, making reports, and/or do some performance.

Specifically, for literary learning, the learning steps according to the scientific approach are very much under the learning principles proposed by Moody and Teeuw. According to Moody, the principle for literature teaching can be considered as an effort of teachers to give new experiences to students about various matters relating to real-life that must be experienced, known, traced to be felt. It is based on the understanding that a literary work is essentially a collection of words that must be analyzed or searched for meaning. While according to Teeuw, the process of literary learning should provide more possibility to students to get, to know, and to be familiar with literary works, especially with existing conventions. This teaching model will help to develop students' sensitivity to the convention. As a result, the students will easily recognize the basic elements of the complex when interpreting them. In other words, the teaching model in familiarizing the conventions, will help the students to be easier in not only look for meaning but also to give meaning to the text they read through their own experience. The introduction of such conventions can be carried out through heuristic and hermeneutic/retroactive reading. The heuristic reading is more focused on understanding language conventions. While hermeneutic/retroactive reading is more aimed at giving an understanding of poetic conventions. The understanding process is done by looking, reading, repeating, comparing, etc. before concluding as a whole.

The implementation of the above learning principles and steps can be carried out as follows:

Learning Objectives / Basic Competencies:

1. Understand the structure and rules of short story texts, both through oral and written.

2. Interpret the meaning of short story texts, both orally and in writing.

Learning materials

- Introduction to the structure of the contents of the short story text

- Introduction to the language characteristics of short story texts

- Understanding the contents of the short story text

- Interpretation of content (intrinsic and extrinsic elements) in the short story text. 
Note: The selection of the short story text must consider the following criteria:

- Age of learners

- Students' level of language mastery and language difficulties in the text (grammar and vocabulary diversity)

- Student interest and enthusiasm for the text.

- Background theme. The theme chosen should not be too familiar or familiar to students.

Teaching Steps

1) The teacher presents the short story text, invites students to observe the description relating to the structure of the text, looking for information related to the title of the text. Students are guided to read texts by using heuristic readings to find the meaning of words or sentences denotatively.

2) Based on the meaning of the language convention that found, the teacher helps students in discussing or asking questions in finding concepts, principles, laws, and theories related to the short story. Students are directed to question relating to the structure of the text as well as the content of the text. The teacher directs students to use communicative language that can be understood by other students.

3) The teacher encourages the students to actively dig deeper into the structure and content of short stories through exploration activities. The exploration is intended to reveal the literary and cultural significance of the short story. Hermeneutic/retroactive reading is used to determine intrinsic or extrinsic elements: Theme, Characteristics, Flow, Setting or Message and Mandate or message, the social background of the author's culture / written text.

4) The teacher helps the students in processing the information according to the result of both heuristic and hermeneutic reading, and develop the reasoning by linking the two reading results to predict the meaning of the short story as a whole.

5) The teacher provides opportunities for students to communicate the results of their conclusions both related to the structure of the text (intrinsic and extrinsic) as well as the meaning or message/value of the short story as a whole. Other groups of students are allowed to respond to another group/student presentations.

\section{Conclusion}

Literary learning, according to any curriculum, aims to provide literary knowledge and literary appreciation to the students. It indicates that literary learning in the 2013 curriculum should be designed not only to improve the students' literary knowledge but also to express the meaning or values contained in the literary works. Literary learning that can produce those understanding, should prioritize the process to familiarize students with conventions that bind literary works, such as language conventions, literary conventions, and cultural conventions, through heuristic and hermeneutic readings. 
The 2013 curriculum existence with its main focus on the application of learning according to the scientific approach is in line with the principle that of the disclosure meaning of literary texts. The teacher has to provide new experiences to students about various matters relating to the real-life that must be experienced, known, traced to be felt. The process of intended understanding can be done through observing, reading, repeating, etc, before taking a conclusion. The steps for understanding a literary text can be applied to the learning core through 5 (five) principles according to the scientific approach which are; Observing, questioning, exploring, associating, and communicating/presenting the meaning, message, or value in the literary text.

\section{References}

Alternbernd, Lynn, and Leslie L. Lewis. 1970. A Handbook for the Study of Poetry. London: The Macmillan Company

Bloom, Benjamin, S. 1981. Taxonomy of Educational Objektives: Cognitive Domain. New York: Longman.

Gani, Rizanur. 1986. Pengajaran Sastra Indonesia Respons dan Analisis. Jakarta, Dian Dinamika Press

Harmer, Jeremy. 2001. The Practice of English Language Teaching. Harlow: Longman.

Hill, Knox, C. 1966. Interpreting Literature. Chicago: Chicago University Press, http://www.ase.org.uk/documents/principles-and-big-ideas-of-science-education

Kementrian Pendidikan dan Kebudayaan Direktorat Jenderal Pendidikan Menengah

Direktorat PSMA. 2013. Pembelajaran Berbasis Kompetensi Mata Pelajaran Bahasa Indonesia Melalui Pendekatan Saintifik.

Moody, H., L., B., 1971. The Teaching of Literature with Special Reference to Developing Countries. London: Longman Group LTD.

Noth, Winfried. 1990. Handbook of Semiotics. Bloomington and Indianapolis: Indiana University Press.

Nunan, David. 1982. Mengembangkan Pemahaman Wacana Teori dan Praktek. Terjemahan Elly, W., Silangen. Jakarta: PT. Rebia Indah Perkasa.

Nurgiyantoro, Burhan. 2002. Teori Pengkajian Fiksi. Yogyakarta: Gajah Mada University Press 
Palmer, Richard, E. 2003. Hermeneutika Teori Baru Untuk Interpretasi, terjemahan Musnur Hery dan Damanhury Muhammed. Yogyakarta: Penerbit Pustaka Pelajar,

Permendikbud No.69 Tahun 2013 tentang Kerangka Dasar dan Struktur Kurikulum Sekolah Menengah Atas/Madrasah Aliyah.

Riffaterre, Michael. 1984. Semiotics of Poetry. Bloomington-London: Indiana University Press

Reaske, Russel, Christopher. 1966. How to Analyze Poetry. New York: Simon \& Schuster Inc.

Suminto. Makalah pada Seminar Nasional Pembelajaran Bahasa dan Sastra Indonesia dalam Kurikulum 2013, di Pascasarjana UNS, Solo, Jawa Tengah, Senin (15/7/2013).

Teeuw, A. 1984. Sastra dan Ilmu Sastra. Pengantar Teori Sastra. Jakarta: Pustaka Jaya

- Membaca dan Menilai Sastra. Jakarta: PT.Gramedia, 1991 UU No 20 tahun 2003 tentang Sistem Pendidikan Nasional (lembar Negara RI tahun 2003 No. 78, Tambahan lembar Negara RI No. 4301),

Werlich, Egon. Praktische Methodik des Fremdspracheunterricht mit Autentischen Texten. Berlin: Cornelsen, 1986.

Young, Jolee. And Elaine Chapman (2010). Generic Competency Frameworks: a Brief Historical

Overview. Education Research and Perspectives, Vol.37. No.1. The University of Western Australia. Z 